\title{
Assessment of the adhesive capacity of asphalt binders in the aggregate- binder bonds by means of new methodology.
}

\author{
Gonzalo Valdés Vidal (Main and Contact Author) \\ Universidad de La Frontera, Departamento de Ingeniería \\ de Obras Civiles \\ $+56 / 45 / 2325680$ \\ Francisco Salazar 01145, Temuco, Chile. \\ gonzalo.valdes@ufrontera.cl
}

\author{
Rodrigo Miró Recasens \\ Universidad Politécnica de Cataluña. \\ r.miro@upc.edu
}

\author{
Adriana Martínez Reguero \\ Universidad Politécnica de Cataluña. \\ adriana.martinez@upc.edu
}

\begin{abstract}
Resumen
El principal objetivo de este estudio es presentar una nueva metodología para caracterizar la capacidad adhesiva (capacidad conjunta de cohesión y adhesión) de los cementos asfálticos mediante nuevos parámetros mecánicos. Esta nueva metodología está basada en el ensayo Fénix, desarrollado recientemente en España. Este método permite evaluar la resistencia a fisuración de las mezclas asfálticas, pero ha sido modificado para caracterizar el poder adhesivo de los cementos asfalticos. Los principales parámetros obtenidos están relacionados con la energía disipada en la ruptura de los puentes de adherencia entre el árido y el ligante cuando estos materiales están sometidos a esfuerzos de tracción. Los resultados de la fase experimental de investigación son presentados en este artículo, los cuales derivan de la aplicación de la nueva metodología propuesta para evaluar el comportamiento del cemento asfáltico en la matriz áridoligante de acuerdo a la variación de la temperatura, el efecto del agua y el envejecimiento, tomado en cuenta áridos del mismo origen, pero diferente forma geométrica. Los resultados obtenidos muestran que la metodología propuesta permite caracterizar la capacidad adhesiva de los cementos asfálticos para las condiciones evaluadas.
\end{abstract}

Palabras clave: Ligante de asfalto, aglomerante de agregado ligante, capacidad adhesiva, ensayo Fénix.
Abstract

The main goal of this study is to present a new methodology to characterize the adhesive capacity (cohesion and adhesion capacity) of asphalt binders by means of new mechanical parameters. This methodology is based on the Fenix test, a test recently developed in Spain. This method assesses the cracking resistance of the asphalt mixtures, and it has been adapted to characterize the bonding power of asphalt binders. The main parameters achieved with this procedure are related to the energy dissipated during the breaking between the asphalt binder and the aggregate, when these materials are subjected to tensile stress; essential parameters related to the adhesive capacity of asphalt binders. The results of an experimental stage are presented in this research, in which the proposed methodology has been applied to analyse the behaviour of the binder in the aggregate-binder matrix according to temperature variation and the effect of water and ageing; taking into account aggregates of the same origin and with a different shape pattern. The results show that the parameters achieved from this new methodology allows characterizing the adhesive capacity of asphalt binders in the different conditions assessed.

Keywords: Asphalt binders, aggregate-binder bonds, adhesive capacity, cohesion, Fénix test.

\section{Introduction}

Asphalt mixtures are the most widely used material in the construction of road pavements (Norambuena, Castro, Del Coz, \& García, 2011). However, bonding failure between the asphalt binder and the aggregate surface is one of the main causes of distress occurring in asphalt pavements. The bonding failure is caused by a combination of two types of failure: cohesive and adhesive failure. Cohesive failure happens when bonds rupture between molecules in the asphalt film. On the other hand, adhesive failure happens when bonds between molecules of different phases (i.e., aggregate and asphalt) rupture (Valdés, Miró, Martínez, \& Calabi, 2014). Since this work studies the aggregate-asphalt interaction (two different materials) the adhesive capacity concept will be used as the binder combined capacity related to the cohesive and adhesion forces that intervene together in the aggregate-asphalt matrix failure.

Adhesion and cohesion asphalt binder properties in asphalt mixtures are basic and essential for the right functioning and durability of flexible pavement structures (Airey G. , 2011; Airey,
Collop, \& Elliot, 2007; Jakarni, 2012; Moreno, García, Rubio, \& Martínez, 2014; Pérez \& Bardesi, 2006). The characterization of the behaviour of the asphalt binder has been frequently carried out, basically, by means of simple tests that assess only partially the properties of the binder, and generally to a certain controlled temperature, for instance penetration, softening point, ductility, fragility point, viscosity, among others (Pérez \& Bardesi, 2006; Pérez \& Miró, 2002). However, these traditional procedures do not assess the main property of the asphalt binder: to provide the right adhesive capacity or bonding power to the aggregates particles in an asphalt mixture, which does not depend only on the binder features, but also on the physical characteristics -or properties- of the aggregate it is interacting with, just as it happens in the highway (Valdés, Calabi, Miró, \& Osses, 2013; Airey G., 2011; Chen, Chan, \& Lin, 2005). Additionally, the different climate conditions of a country make the adhesive characteristic of aggregates - according to the thermal susceptibility of asphalt pavement - to be a very influential factor in the structural and functional behaviour of an asphalt mixture in the pavement (Aguiar, et al., 2013). This adhesive characteristic is usually not taken into account during the stages of assessment and design of the material. 
In the same context, there are two other phenomena that influence on the adhesive capacity a binder can provide to the aggregate-binder matrix. One of those is moisture damage or water sensitivity. This phenomenon is characterized by a loss of adhesion, which causes a type of malfunctioning, typically accompanied by the debonding of the binder from the aggregate surface, as a result of water penetration in the aggregate-binder interface (Airey, Collop, \& Elliot, 2007; Aguiar, et al., 2013; Caro-Spinel \& Alvarez-Lugo, 2002; Botasso, Balige, González, Bisio, \& Berardo, 2005). From this phenomenon, numerous types of damages stem from adhesiveness failure, such as: ravelling of the mixture, tyre-markings, superficial debonding and fatigue cracks, which if not repaired, can lead to severe pavement structural damage, which in turn, derive in an early loss of serviceability, therefore, of their life span (Jakarni, 2012).

The other phenomenon that affects the adhesive capacity of a binder is ageing. This process is characterized by a hardening of the binder due to an oxidation process (Lu \& Isacsson, 2002). During this process some oxidized products generate, such as carboxylic acids, sulfoxyde anhydrid and ketones, all polar compounds. This increase in the polarity of the system causes a phenomenon of adding tarmac molecules, turning them into bigger and heavier molecules. (Airey G. , 2003; Pérez \& Miró, 2001; Read \& Whiteoak, 2003). This process causes the binder to stiffen up making it more fragile; allowing the presence of cracks through which water can leak, damaging the pavement structure (Malan, Straus, \& Hugo, 1989; Nesnas \& Nunn, 2004).

According to what has been mentioned before, it is possible to make clear the importance of the proper evaluation, for asphalt pavement structures, of the adhesion property that asphalt binders can provide to aggregates, which varies according to the physical properties of aggregates, the thermal susceptibility, the effect of water and the ageing of the asphalt binder.

Consequently, the main goal of this research study is to present a new methodology based on an adaptation of the Fénix test procedure (Valdés, Pérez-Jiménez, \& Botella, 2009; Miró, Martínez, Pérez, Botella, \& Valdés, 2012), to asses the adhesion that different types of asphalt binders have on different aggregates, considering the effects of temperature variations, water effect and ageing.

\section{METHODOLOGY AND TESTING PLAN}

\section{Modified Fénix Test}

This section presents the methodology used for the present research, based mainly on the modification of the load application speed of the Fenix test and the usage of specimens manufactured with the aggregate gradation used in the Universal Method for the Characterization of Binders, UCL (Spanish name of the method) (Pérez \& Miró, 2002). The adapted procedure consists in subjecting half a cylindrical specimen - with a $6 \mathrm{~mm}$ deep notch in the central axis - to a tensile stress, at a speed of $10 \mathrm{~mm}$ per minute. The specimens are manufactured according to the $U C L$ method using the Marshall procedure, applying 50 blows per side and with a fixed binder content of $4.5 \%$ (by weight of the aggregate) and a gradation composed of $80 \%$ of aggregate size between 2.5 and $5 \mathrm{~mm}$ and $20 \%$ of aggregate size between $0.63 \%$ and $2.5 \mathrm{~mm}$. Once the specimen has been cut and notched, its flat sides are fixed to steel plates which in turn are fixed to the press pistons, allowing a rotation movement about fixing points during the tensile stress, Figure 1.

During the carrying out of the test, the generated loads in relation to the displacements are recorded with a data collector device. Using this data a load-displacement curve is plotted, which makes possible to obtain the mechanic parameters that characterize the behaviour of the binder. The main parameters obtained from these load-displacement curves are: the peak load, Fmax, the tensile stiffness index (equation 1), the displacement after load-peak to $50 \%, \Delta$ mdp, the dissipated energy in the breaking process, GD (equation 2) and the tenacity index, IT (equation 3).

$\mathrm{IRT}=\frac{1 / 4 \mathrm{Fmax}}{\Delta \mathrm{m}-\Delta \mathrm{c}}$

IRT : tensile stiffness index $(\mathrm{kN} / \mathrm{mm})$

Fmax : peak load (kN)

$\Delta \mathrm{m} \quad$ : displacement before peak load at $1 / 2 \mathrm{Fmax}(\mathrm{mm})$.

$\Delta c \quad$ : displacement before peak load at $1 / 4 \mathrm{Fmax}(\mathrm{mm})$.

$\mathrm{G}_{\mathrm{D}}=\frac{\int_{0}^{\Delta \mathrm{R}} \mathrm{F}(\mathrm{x}) \cdot \mathrm{dx}}{\mathrm{S}}$

GD : dissipated energy in break process $(\mathrm{J} / \mathrm{m} 2)$

$\mathrm{F} \quad$ : load $(\mathrm{kN})$

$\mathrm{X} \quad$ : displacement ( $\mathrm{mm})$

$\Delta \mathrm{R} \quad$ : breaking displacement $(\mathrm{mm})$

$\mathrm{S} \quad$ : breaking area $(\mathrm{m} 2)$

$\mathrm{I}_{\mathrm{T}}=\frac{\int_{\leftrightarrows \mathrm{Fmax}}^{\leftrightarrows \mathrm{R}} \mathrm{F}(\mathrm{x}) \cdot \mathrm{dx}}{\mathrm{S}} \times\left(\Delta_{\mathrm{mdp}}-\Delta_{\mathrm{Fmax}}\right)$

(3)

IT : tenacity index ( $\mathrm{Jm} / \mathrm{m} 2)$.

$\leftrightarrows$ Fmax : displacement to Fmax (mm).

$\leftrightarrows_{\text {mdp }} \quad$ : displacement after peak load to $1 / 2 \mathrm{Fmax}(\mathrm{mm})$.

$\mathrm{S} \quad$ : breaking area $(\mathrm{m} 2)$

In order to evaluate the temperature effect over the adhesion the binder provides to aggregates the Fenix test was carried out to temperatures of $-10^{\circ} \mathrm{C}, 0^{\circ} \mathrm{C}, 10^{\circ} \mathrm{C}$ and $20^{\circ} \mathrm{C}$. Also evaluated were the effect of water and ageing after conditioning the specimens according to the UCL method; in order to evaluate the effect of water in the adhesiveness of the binders, the specimens are submerged in water at $60^{\circ} \mathrm{C}$ during 24 hours, and to evaluate the effect of ageing, the specimens are introduced in an oven with forced ventilation at $80^{\circ} \mathrm{C}$ during periods of 2 and 8 days (Pérez $\&$ Bardesi, 2006).

In order to evaluate the influence of the type of binder, five asphalt binders were used: three conventional penetration binders, one modified with polymers and one of high modulus. 


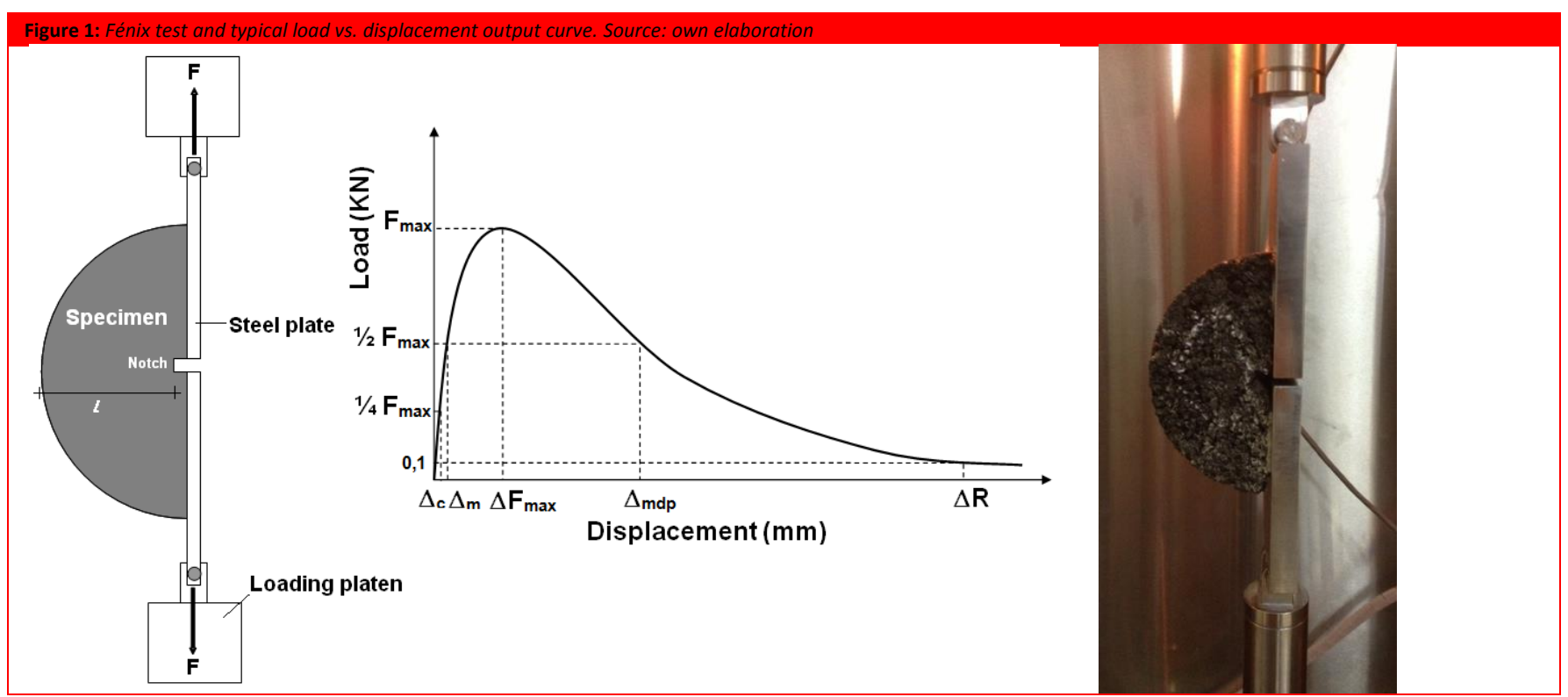

\section{MATERIALS}

Asphalt binders

Five different asphalt binders were selected: three of them conventional binders, two of them were classified into the CA24 category (according to the Chilean specifications), but with different viscosity, and one was classified into the category CA14. Besides, one asphalt binder modified with $5 \%$ of polymers SBS (CA-MP) was also evaluated, and one high modulus asphalt binder (CA-AM). The properties of binders used in the study are shown in tables 1 and 2.

\section{Aggregates}

Two different fluvial aggregates were used. The physical properties of the aggregates are shown in table 3, while their shape properties, obtained by means of the methodology put forward by Cheng and others (Chen, Chan, \& Lin, 2005), are shown in table 4.

The fluvial aggregates used correspond to a processed material obtained from the Cautin River in the 9th region of Chile. These aggregates are composed mainly of dolomite particles, basalt, dacites, andesites, rhyolites, sandstone, quartz and quartzite (Moreno \& Varela, 1985). The main difference between both fluvial aggregates is their final crushing process: the sphereparticles aggregate (AF2) was obtained from the use of an impact crusher, whereas the more irregular-shaped aggregate (AF1), was obtained from the use of a cone crusher, table 4.

\begin{tabular}{|c|c|c|c|c|}
\hline Tests & $\begin{array}{l}\text { CA-24 } \\
\text { (1) }\end{array}$ & $\begin{array}{l}\text { CA- } \\
24 \\
\text { (2) }\end{array}$ & $\begin{array}{l}\text { CA- } \\
14\end{array}$ & Specs. \\
\hline Absolute Viscosity at $60^{\circ} \mathrm{C}$, & 3455 & 2410 & 1833 & $(*)$ \\
\hline $300 \mathrm{~mm} \mathrm{Hg}(P)$ & $>105$ & $>105$ & $>105$ & Min 100 \\
\hline Ductility at $25 \circ \mathrm{C},(\mathrm{cm})$ & $<30$ & $<30$ & $<30$ & Max 30 \\
\hline Oliensis Spot Test, (\% xylene) & $>232$ & $>290$ & $>290$ & Min 232 \\
\hline $\begin{array}{l}\text { Cleveland Open Cup Flash } \\
\text { Point, }\left({ }^{\circ} \mathrm{C}\right)\end{array}$ & 50 & 51.8 & 51.8 & $\begin{array}{l}\text { To be } \\
\text { reported }\end{array}$ \\
\hline Softening Point R\&B, (ํ) & -1.4 & -1.7 & -1.9 & $\begin{array}{ll}-2.0 & a \\
+1.0\end{array}$ \\
\hline \multicolumn{5}{|l|}{ Penetration Index } \\
\hline \multicolumn{5}{|l|}{ RTFOT } \\
\hline Mass Loss, (\%). & 0.24 & 0.4 & 0.4 & Max 0.8 \\
\hline $\begin{array}{l}\text { Absolute Viscosity at } 60 \text { ㅇ, } \\
300 \mathrm{~mm} \mathrm{Hg}(\mathrm{P})\end{array}$ & 10952 & 7230 & 3911 & $\begin{array}{l}\text { To be } \\
\text { reported }\end{array}$ \\
\hline & $>105$ & $>105$ & $>105$ & Min 100 \\
\hline $\begin{array}{l}\text { Ductility at } 25 \stackrel{\circ}{\circ}, 5 \mathrm{~cm} / \mathrm{min} \\
\text { Durability Index }\end{array}$ & 3.2 & 3.0 & 2.1 & Max 3.5 \\
\hline
\end{tabular}

Table 2. Properties of non-conventional asphalt binders evaluated 


\begin{tabular}{|c|c|c|c|c|}
\hline Tests & $\begin{array}{l}\text { CA- } \\
\text { MP }\end{array}$ & Specs. & $\begin{array}{l}\text { CA- } \\
\text { AM }\end{array}$ & Specs. \\
\hline Penetration at $25^{\circ} \mathrm{C}, 100 \mathrm{~g}$. & 65 & $60-80$ & 14 & $12-17$ \\
\hline $5 \mathrm{~s} .(0.1 \mathrm{~mm})$ & 76 & $\operatorname{Min} 60$ & 65 & Min. 65 \\
\hline Softening Point R\&B, $\left({ }^{\circ} \mathrm{C}\right)$ & 52 & Min 50 & - & - \\
\hline Ductility at $5^{\circ} \mathrm{C}(\mathrm{cm})$ & 98 & Min 80 & - & - \\
\hline Ductility at $25^{\circ} \mathrm{C}(\mathrm{cm})$ & 4.5 & $\operatorname{Min}+2$ & -0.62 & Min. \\
\hline Penetration Index & -18 & Max -17 & -3 & 1.5 \\
\hline $\begin{array}{l}\text { Fraass Brittle Point, }(\stackrel{\circ}{ } \mathrm{C}) \\
\text { Elastic Recovery }\left(13^{\circ} \mathrm{C}, 20\right.\end{array}$ & 66 & $\begin{array}{l}\text { To be } \\
\text { reported }\end{array}$ & - & Max. -5 \\
\hline $\mathrm{cm}, 1 \mathrm{hr}, \%)$ & 240 & Min 235 & $>$ & \\
\hline $\begin{array}{l}\text { Cleveland Open Cup Flash } \\
\text { Point, }\left({ }^{\circ} \mathrm{C}\right)\end{array}$ & - & - & 1709 & $\begin{array}{l}240 \\
\text { Min. }\end{array}$ \\
\hline Brookfield Viscosity at & & & $152 ?$ & 1200 \\
\hline $\begin{array}{l}\text { Brookfield Viscosity at } \\
160^{\circ} \mathrm{C}(\mathrm{cP})\end{array}$ & & & 453.3 & 350 \\
\hline RTFOT & & & & \\
\hline $\begin{array}{l}\text { Retained Penetration, (\%). } \\
\text { Softening Point R\&B } \\
\text { Increase, }(\stackrel{\circ}{ } \text { ) }\end{array}$ & & & $\begin{array}{l}64 \\
9\end{array}$ & $\begin{array}{l}\text { Min. } 55 \\
\text { Max. } \\
10\end{array}$ \\
\hline
\end{tabular}

susceptibility the test was executed at the temperatures of -10

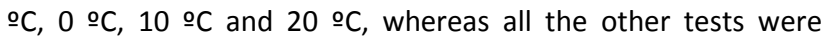
carried out at only one temperature of $10^{\circ} \mathrm{C}$. For each evaluated variable, 3 specimens were tested.

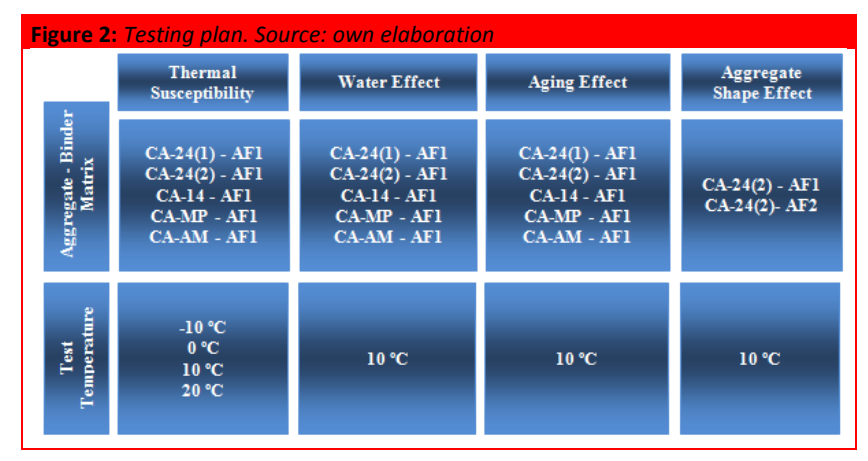

RESULTS ANALYSIS

\begin{tabular}{llllll}
\hline \multicolumn{7}{l}{ Table 3. Properties of aggregates. Source: own elaboration } & \\
\cline { 2 - 5 } Tests & AF1 & AF1 & AF2 & AF2 & \\
\cline { 2 - 5 } & $\begin{array}{l}\mathbf{( 5 - 2 . 5 )} \\
\mathbf{m m}\end{array}$ & $\begin{array}{l}\mathbf{( 2 . 5 -} \\
\mathbf{0 . 6 3}) \\
\mathbf{m m}\end{array}$ & $\begin{array}{l}\mathbf{( 5 - 2 . 5 )} \\
\mathbf{m m}\end{array}$ & $\begin{array}{l}\mathbf{( 2 . 5 -} \\
\mathbf{0 . 6 3 )} \\
\mathbf{m m}\end{array}$ & Specifications \\
\hline $\begin{array}{l}\text { Los Angeles } \\
\begin{array}{l}\text { Abrasion Loss } \\
(\%)\end{array}\end{array}$ & 25 & - & 14.3 & - & $<25-35 \%$ \\
$\begin{array}{l}\text { Specific } \\
\begin{array}{l}\text { Gravity } \\
\left(\mathrm{kg} / \mathrm{m}^{3}\right)\end{array}\end{array}$ & 2792 & $\begin{array}{l}266 \\
0\end{array}$ & 2776 & $\begin{array}{l}270 \\
1\end{array}$ & $2000-3000$ \\
\hline $\begin{array}{l}\text { Absorption } \\
(\%)\end{array}$ & 2.5 & 0.7 & 1.8 & 1.6 & $<3$ \\
\hline
\end{tabular}

\begin{tabular}{|c|c|c|}
\hline Aggregate & AF1 & AF2 \\
\hline $\begin{array}{l}\mathrm{dL} \\
(\mathrm{mm})\end{array}$ & 6.59 & 5.55 \\
\hline $\begin{array}{l}\text { dl } \\
(\mathrm{mm})\end{array}$ & 3.91 & 3.99 \\
\hline $\begin{array}{l}\text { dS } \\
(\mathrm{mm})\end{array}$ & 2.21 & 2.78 \\
\hline Elongation ratio & 0.59 & 0.72 \\
\hline Flatness ratio & 0.56 & 0.70 \\
\hline Shape factor & 0.43 & 0.59 \\
\hline Sphericity factor & 0.58 & 0.71 \\
\hline Particle Index & 20.3 & 14.6 \\
\hline \multirow[t]{2}{*}{ PI } & $\mathrm{V} 10=51.8 \%$ & $V 10=46.1 \%$ \\
\hline & V50=50\% & $V 50=44.3 \%$ \\
\hline
\end{tabular}

\section{Thermal Susceptibility}

The Fenix parameters obtained at different temperatures for each asphalt binder are shown in the corresponding loaddisplacement curves in Figure 3. Both, the peak load, Fmax, and the tensile stiffness index, for all the asphalt pavements, decrease according to the rise in the test temperature. As the temperature rises, the binders are more ductile and their capacity to present higher displacements increases. In terms of dissipated energy in breaking process, $G \neg D$, -which is directly connected with the work carried out during the breaking process of the aggregate-binder bonds of the evaluated binders (area under the load-displacement curve)- it is noticed that it rises as the binders take higher load-peaks and high break displacements. Finally, another parameter related to the energy in the post-peak process is the tenacity index, IT; this parameter shows the capacity of the binder to keep the aggregates together, once the breaking of the aggregate-binder bonds has begun after reaching Fmax. For the different binders assessed, the tenacity index shows its peak values when the binders are able to hold the aggregate particles together, dissipating more energy at higher deformations. For the conventional binders this peak occurs at $10^{\circ} \mathrm{C}$, while for the polymer-modified binder this occurs at $0^{\circ} \mathrm{C}$, and for the high-modulus binder this event occurs at $20^{\circ} \mathrm{C}$, as consequence of their different stiffness.

Testing plan

The testing plan is shown in Figure 2. For each condition evaluated three specimens were tested by the modified Fénix test and average parameters were analyzed. The evaluation of the effect of temperature, water and ageing in the bonding power of aggregates was made using the five binders showed in table 1 and the aggregate AF1. Additionally, tests were made to evaluate the methodology's sensibility concerning aggregates of different shapes. In order to do so, specimens were made using the two types of aggregates included in table 4 and only one asphalt binder, CA-24 (2). For the study of the thermal

In general terms, the different asphalt binders assessed, show a similar behaviour tendency to a change of temperature. At low temperatures $\left(-10^{\circ} \mathrm{C}\right)$, both the conventional and the nonconventional binders show a higher stiffness and a more fragile failure, bearing high peak loads (Fmax), and showing low break displacements $(\Delta R)$. While this is so at low temperatures, at higher test temperatures $\left(20^{\circ} \mathrm{C}\right)$ their stiffness decreases, bearing lower peak loads and increasing their capacity to take deformations. When test temperatures are mild $\left(0^{\circ}\right.$ and $\left.10^{\circ} \mathrm{C}\right)$ the assessed binders (except the high-modulus binder) show a higher tenacity and a higher dissipated energy during the breaking process of the aggregate-binder bonds, combining a good capacity to bear loads with a high deformation capacity. The high-modulus binder showed the bigger tenacity, therefore 
the higher capacity to keep the aggregate-binder bonds, at the highest test temperatures, as consequence of its high stiffness, while the polymer-modified binder did so at the lowest, as consequence of its lower stiffness.

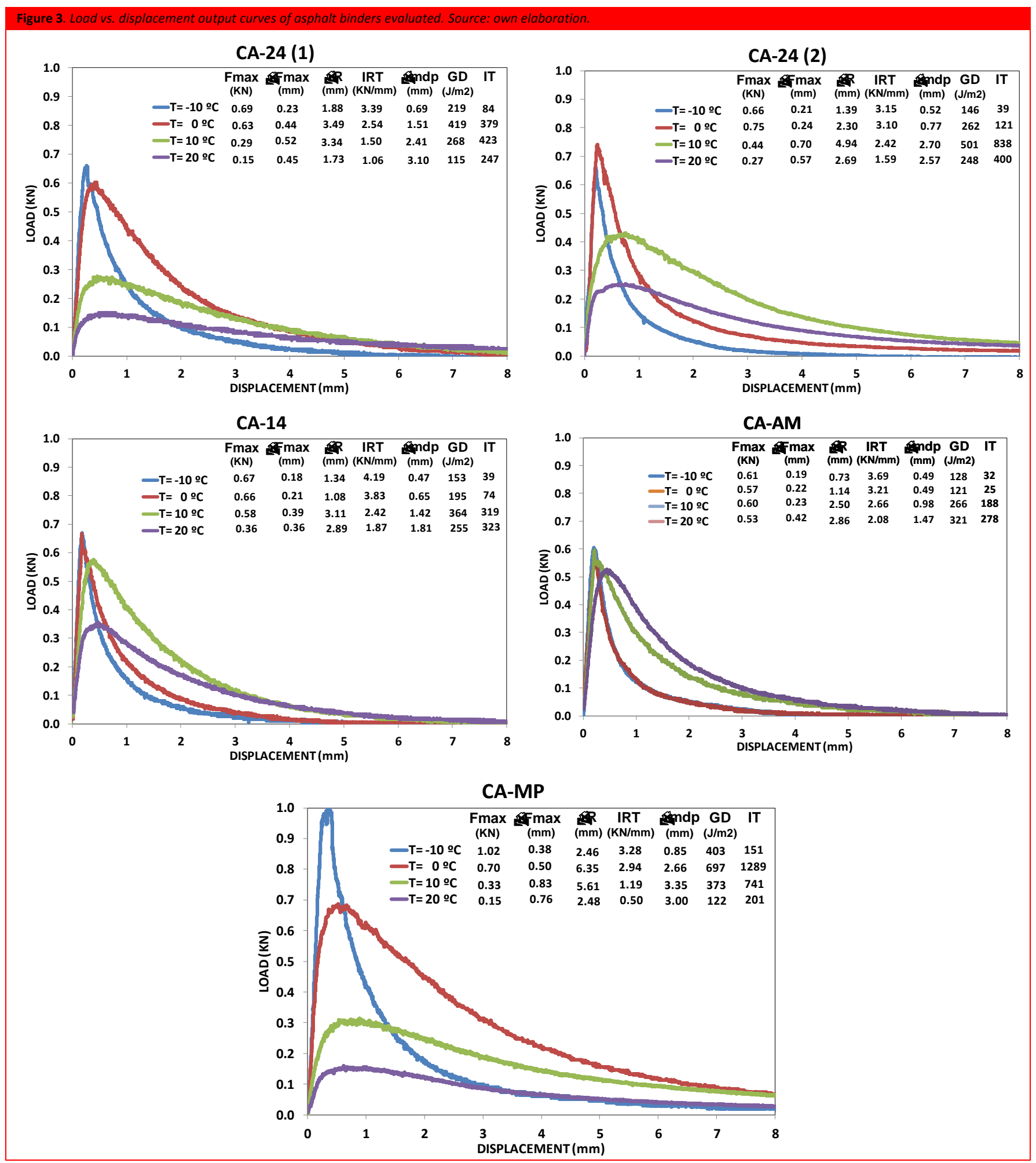


Water and Ageing Effect

Figure 4 shows the load-displacement curves for the AF1-CA24 (2) after water immersion (a) and ageing (b). In Figure 4(a) it is noticed that, after immersion, the binder loses adhesive capacity given that water reaches the aggregate-binder interface, causing the stripping of the binder from the aggregate surface, which causes in turn a decrease in the binder's capacity to bear loads, and, consequently, both the Fmax and IRT decrease. On the other hand, the dissipated energy during the breaking process of the aggregate-binder bonds, GD, as well as the tenacity index, IT, decrease noticeably in all asphalt binders, as shown in Figure 5 .

In Figure 4(b) are shown the load-displacement curves after subjecting the binder to the ageing process. As consequence of this oxidation experienced, the binder stiffens up, which results in a higher fragility. This appears evident in the load- displacement curves, given that Fmax as well as IRT are higher after ageing, showing that the binder's capacity of post-peak displacements, $\Delta$ mdp, decreases considerably. Therefore, the tenacity index decreases, since once the breaking of the aggregate-binder bonds has begun, the energy dissipates with a very low displacement. The rise in stiffness and the decrease of deformation and tenacity are a common factor to all asphalt binders evaluated, as shown in Figure 6 . At this test temperature, $10^{\circ} \mathrm{C}$, the dissipated energy, GD, also decreases after ageing, but it may not be the case at different temperatures, since this parameter is the result of the combination of the capacity to bear loads and to take deformations; increasing the first while diminishing the latter, as consequence of stiffening after ageing.
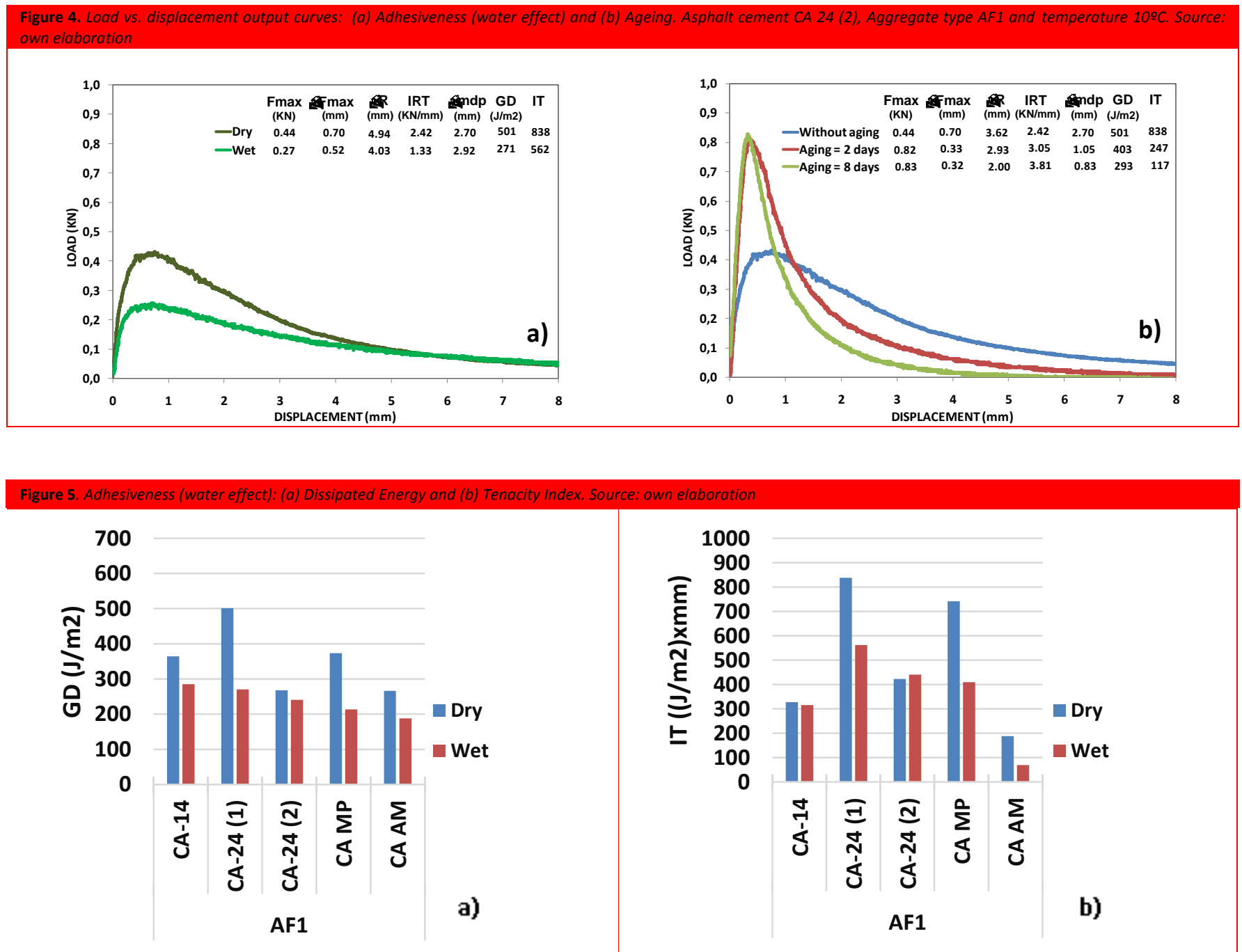


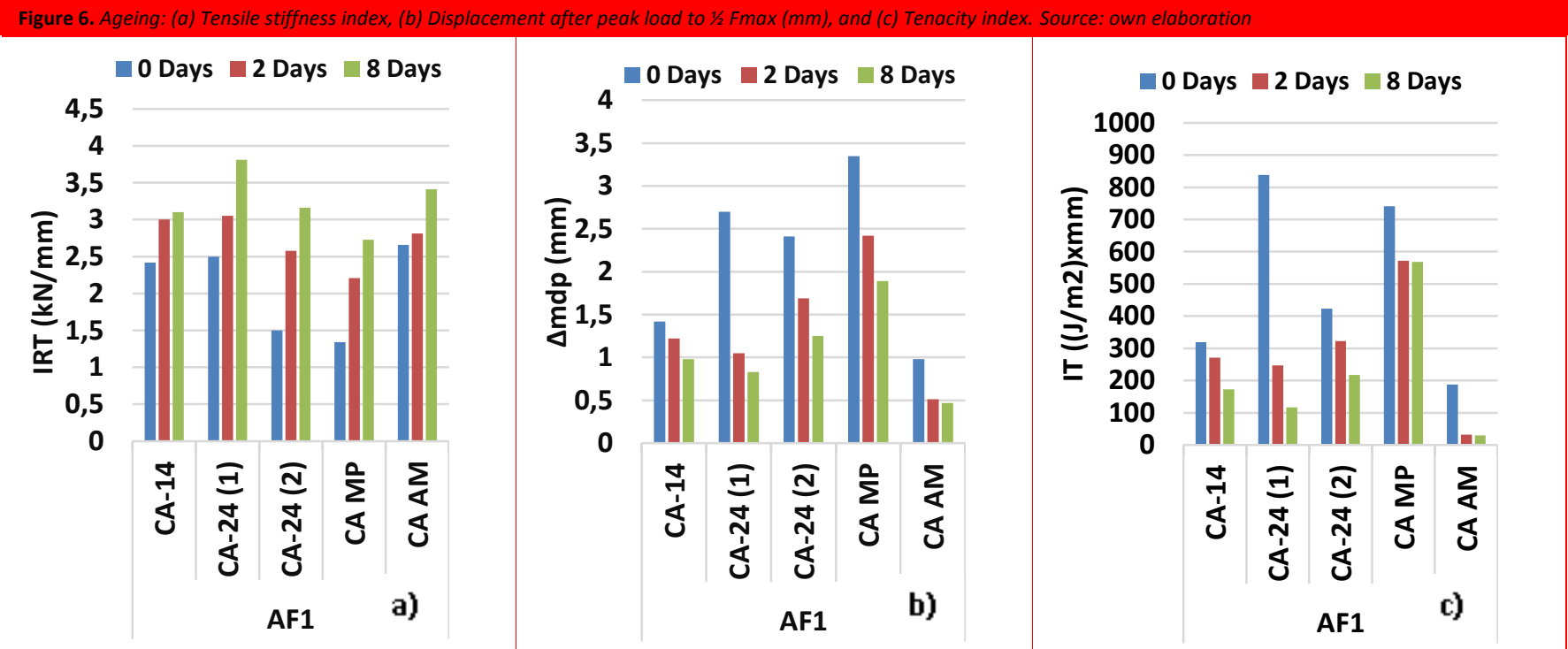

Aggregate Shape Effect

Figure 7 shows the load-displacements curves for two aggregate-binder matrices, formed by the asphalt binder CA-24 (2) and the two evaluated aggregates. In general, the evaluated binder showed a better adhesion to aggregate AF1 than to AF2, since it presents a higher capacity to bear loads along with a higher deformation capacity, which indicates a higher tenacity index, and in this case, a higher dissipated energy during the breaking process of aggregate-binder bonds, GD.

Concerning shape parameters shown in table 4 , it is noticed that for the particle index, the aggregates AF1 and AF2, obtained particle index values of 20.3 and 14.5 correspondingly. According to results presented by Chen and others (Chen, Chan, $\&$ Lin, 2005), the high values of particle index show that the aggregate has a better behaviour due to a high inner friction. When noticing the behaviour of the AF1 aggregate (highest particle index value), it is possible to see that it showed higher values in parameters related to tenacity of the aggregate-binder bonds, therefore, a better adhesion between the asphalt binder and the aggregate's surface. On the contrary, the adhesion granted by the binder to the AF2 aggregate (lower particle index value) was noticeably lower. As Airey has pointed out (Airey G. , 2011), these results may be so given that the more irregular-shaped aggregates that obtained a higher particle index value, has more texture and contact surface among aggregates, therefore, their aggregate-binder bonds are more resistant than those of aggregates with a lower particle index value.

The methodology proposed, based on the application of the modified Fenix test over specimens manufactured with the $\mathrm{UCL}$ Method aggregate gradation, allows characterizing adhesive properties of asphalt binders to aggregates, based on mechanical parameters such as stiffness, deformation capacity and tenacity of unions between asphalt binders and aggregates; being tenacity index the one that best evaluates this last property: the higher the tenacity index, the better the adhesive capacity an asphalt binders has. By using this methodology, it is possible to analyse the effects of temperature, water and ageing in the adhesive capacity of binders in contact with aggregates, after conditioning the specimens manufactured according to the UCL procedure. Besides, the Fenix test modified method allows evaluating the adhesive capacity of the asphalt binders, taking into account the physical characteristics of the aggregate.

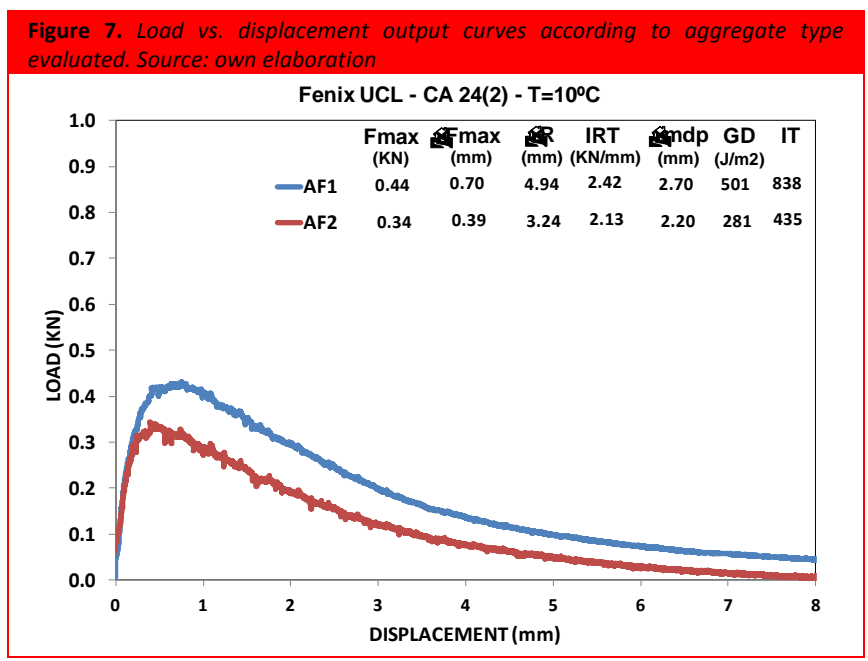

ACKNOWLEDGMENTS

The present article is the result of the research supported by CONICYT program, conducted within the framework of the FONDECYT INICIACION Project № 11130723.

\section{REFERENCES}

Aguiar, J., Loria, L., Salazar, J., Villegas, E., Corrales, J. and Hajj, E. (2013). Evaluation of Adhesion Properties of Costa Rican Asphalt Mixtures Using the Bitumen Bond Strehgth (BBS). 92th Annual Meeting of the Transportation Research Board. Washington. 
Airey, G. (2003). State of the Art Report on Ageing Test Method for Bituminous Pavement Materials. The International Journal of Pavement Engineering, 4(3), 165-176.

Airey, G. (2011). Adhesion and Moisture Damage Chracterization of Asphalt Mixtures. Asphalt Seminars. Granada.

Airey, G., Collop, A. Z., and Elliot, R. (2007). Moisture Damage Assessment of Asphalt Mixtures Using the UK SATS Test. Transportation Research Board 86th Annual Meeting. Washington.

Botasso, G., Balige, M., González, R., Bisio, A., and Berardo, A. (2005). Nueva Metodología para la Valoración de la Adherencia árido ligante. XIII Congreso Ibero-Latinoamericano del Asfalto. San Jose.

Caro-Spinel, S., \& Alvarez-Lugo, A. (2002). Evaluación de la Suceptibilidad al Daño por Humedad de Mezclas Asfálticas Empleando Propiedades Termodinámicas. Revista Facultad de Ingeniería Universidad de Antioquia, Vol 58, 95-104.

Chen, J., Chan, M., \& Lin, K. (2005). Influence of Coarse Aggregate Shape on The Strength of Asphalt Concrete Mixtures. Journal of the Eastern Asia Society for Transportation Studies, Vol 6, 1062-1075.

Jakarni, F. (2012). Adhesion of Asphalt Mixtures. PhD Thesis. University of Nottingham (Thesis in English).

Lu, X., \& Isacsson, U. (2002). Effect of aging on bitumen chemistry. Construction and Building Materials, 16(1), 15-22.

Malan, G., Straus, P., \& Hugo, F. (1989). A Field Study of Premature Surface Cracking in Asphalt. Association of Asphalt Paving Technologists, Vol 58, 142-162.

Miró, R., Martínez, A., Pérez, F., Botella, R., and Valdés, G. (2012). Assessment of Cracking Resistance of Bituminous Mixtures by Means of FENIX Test. 7th RILEM International conference on Cracking Pavement. The Netherrlands.

Moreno, F., García, G., Rubio, M., \& Martínez, M. (2014). Analysis of the moisture susceptibility of hot bituminous mixes based on the comparison of two laboratory test methods. DYNA, 49-59.

Moreno, H., \& Varela, J. (1985). Geología, volcanismo y sedimentos piroclásticos cuaternarios de la Región Central y Sur de Chile. En J. Tosso, Suelos volcánicos de Chile (págs. 491-526). Santiago: Instituto de Investigaciones Agropecuarias.

Nesnas, K., and Nunn, M. (2004). A Model For Top-Down Reflection Cracking in Composite Pavements. Fifth International RILEM Conference on Reflective Cracking in Pavements, Limogoes.

Norambuena, J., Castro, D., Del Coz, J., \& García, P. (2011). Simulación numérica de una mezclas asfáltica usando MEF y diseño de experimentos. Revista de La Construcción, 10(2), 5-15.

Pérez, F., \& Bardesi, A. (2006). Manual para la Caracterización de Ligantes y Másticos Bituminosos. Madrid: Repsol YPF.

Pérez, F., \& Miró, R. (2001). Procedure for the Evaluation of Asphalt Binders Ageing in Contact with Aggregates and Application of this Procedure to Analyze the Influence of the Aggregate Type on Binder Ageing. Road Materials and Pavement Design, 2(1), 97110.

Pérez, F., \& Miró, R. (2002). Nuevos Ensayos para la caracterización de Ligantes Y Mezclas Asfálticas. Revista Carreteras, 28-29.

Read, J., \& Whiteoak, D. (2003). The Shell Bitumen Handbook (5th Edition). London: Thomas Telford Publishing.
Valdés, G., Calabi, A., Miró, R., \& Osses, R. (2013). Caracterización Funcional de La Cohesión de Los Cementos Asfálticos Utilizados en Chile Mediante el Procedimiento UCL. XVII Congreso IberoLatinoamericano del Asfalto. Antigua Guatemala.

Valdés, G., Pérez-Jiménez, F., \& Botella, R. (2009). Ensayo Fénix, una nueva metodología para medir la resistencia a la fisuración de mezclas asfálticas. Revista de la Construcción, 8(1), 114-125.

Valdés, G., Miró, R., Martínez, A., \& Calabi, A. (2014). Effect of the physical properties of aggregates on aggregates -asphalt bond measured using the UCL method. Construction and Building Materials, Vol 73, 399-406. 